\title{
AN EXAMINATION OF THE BLOOD AS AN AID IN THE DIAGNOSIS OF SMIALL-POX.*
}

\author{
BY H. ROGER, M.D., \\ Physician to the Porte d'Aubervilliers Hospital, Paris.
}

THE extreme contagiousness of small-pox makes it a matter of great social importance that the disease should always be recognised. This can almost always be done by a proper appreciation of the objective characters of the eruption. Still, in difficult cases one may have recourse to other methods which, although they are more difficult to carry out, are still none the less important.

It is first necessary to examine the pus in the pustules under the microscope. In the case of pyæmia, acne, and erythema polymorphe, polynuclear bodies with staphylococei in their centres will be found. In small-pox the pus is richer in mononuclear cells, and at the commencement, at least, there are no micro-organisms. On the other hand, there are peculiar small bodies, round or oval, which have been thought, in my opinion reasonably, to be the specific organisms of the disease. If it is a case of hæmorrhagic small-pox, the examination of the blood-stained fluids passed by the patient will show the same elements. It is particularly the examination of the blood which will give the most important clues. In hæmorrhagic small-pox, and in the early stages of the pustules in ordinary small-pox, characteristic corpuscles will be seen. At the same time peculiar changes take place in the leucocytes. The leucocytosis of small-pox is of a mononuclear character, according to Courmont and Montagnard, but a special mononucleosis; it is a myelocytosis similar to the myelocytosis in leukæmia, and which has been described by M. Weil, working with me. The polynuclear cells are always below normal. They vary from 40 to 50 per cent., and in severe cases, notably in hæmorrhagic cases, fall to 20 and even 14 per cent.

The mononuclear cells are the more abundant; 30 to 40 per cent. are found. Beside them one finds large mononuclear neutrophile cells ( 2 to 10 per cent.), some mononuclear eosinophile cells $\left(0^{*} 5\right.$ to 1 per cent.), and a mononuclear cell whose protoplasm (non-granular) has an affnity for nuclear stains (2 to 10 per cent.). One also finds intermediate forms of eosinophile cells, which, numerous enough at the beginning, disappear immediately, to again appear during con-

\footnotetext{
* La Presse Médicale, February 8th, 1902. Extract from translation in Treatment by Percy J. Wilkinson, F.R.C.S., D.P.H.
} 
valeseence. During the period of suppuration and desiccation appear leucocytic forms of the basophile variety, mono- or polynuclear, always in snall numbers. These abnormal forms, abundant at the commencement, last during pustulation, and gradually disappear during convalescence. They are sometimes found at the end of forty days.

The diagnostic value of the condition of the leucocytes is very great. If Tiurk has found neutrophile myelocytes in pneumonia, Enfel in diphtheria, and Nieder in other infectious diseases, their number is very limited. These cells in those diseases are isolated; they are much scattered about. The peculiar blood-forms in small-pox enable a diagnosis to be made from scarlet fever and measles. In measles the polynuclear cells are 75 per cent. of the total leucocytes, and in scarlet fever 85 to 98 per cent. It is only necessary to know that on complications arising the condition may be altered.

But this is not always the case. Thus, in three cases of fatal broncho-pneumonia in children, the polynuclear cells were respectively 14,20 , and 40 per cent. On the other hand, pneumonia supervening in an adult gave 67 per cent. of polynuclear cells. Finally, if the complication takes place during convaleseence, one finds they vary between 65 and 78 per cent.

One disease alone gives similar results-that is, chicken-pox. This is not surprising, for chicken-pox seems to depend on a similar germ to that of small-pox. But the characters of the two diseases are sufficiently well marked for a diagnosis to be made by simple clinical examination.

In conclusion, in doubtful cases of small-pox an examination of the blood enables a diagnosis to be made. This examination is easy enough, but still needs special appliances and knowledge. We frequently use it, and have been able to estimate its value and correctness; but, except in special cases, one ought to be able to spot small-pox from an objective examination.

The Imperial Vaccination League aims at giving a general support to movements in favour of vaccination by means of leaflets, lectures, meetings, and the like. Its president is the Duke of Fife; the treasurer is Lord Avebury, and the provisional committee consists of Dr. Thresh, Dr. J. G. Glover, Dr. J. D. Acland, Dr. Dudfield, Mr. R. Brudenell Carter, Dr. E. Garrett Anderson, the Rev. H. L. Paget, Mr. John Carrington, and Mr. Greenwood. The League intends at once to collect opinions as to what amendments of the Vaccination Act should be urged upon the Government when the time comes for dealing with the subject. 